\title{
Biochemical Quality Assessment of Fish Powder
}

\author{
S. N. Jahan ${ }^{1, *}$, M. A. Bayezid ${ }^{1}$, B. Islam², M. A. B Siddique ${ }^{1}$, P. K. Karmokar ${ }^{3}$, F. A. Flowra ${ }^{1}$ \\ ${ }^{1}$ Department of Fisheries, University of Rajshahi, Bangladesh \\ ${ }^{2}$ Bangladesh Council for Scientific and Industrial Research Laboratories, Rajshahi, Bangladesh \\ ${ }^{3}$ Department of Statistics, University of Rajshahi, Bangladesh \\ *Corresponding author: nusratru@yahoo.com
}

\begin{abstract}
The study carried out with a view to determining proximate and mineral composition of fish powder of five freshwater fish samples (Hypophthalmicthys molitrix, Labeo rohita, Cirrnina mrigala and Puntius sophore and small prawns). The samples collected from five local fish markets of Rajshahi city corporation were subjected to washing, gutting drying and grinding in order to make powder and homogenized sample which were preserved into plastic container for chemical analyses. All the activities were conducted in the laboratory of department of Fisheries, University of Rajshahi, Bangladesh. Major nutrient compositions of powder products such as protein, lipid, moisture, ash, carbohydrate, phosphorus, iron and calcium were estimated. Chemical compositions were found to vary among the species. The protein, lipid, moisture and ash content of five samples ranged from 54.31 (P. sophore) to 68.90\% (small prawns), 13.33 (P. sophore) to 19.33\% (L.rohita), 11.55 (L. rohita) to 13.95\% (H. molitrix) and 0.16 (small prawns) to $0.44 \%$ (C. mrigala), respectively. The highest value of carbohydrate was $19.23 \%$ (P. sophore) and the lowest was $1.75 \%$ (C. mrigala). The calcium, iron and phosphorus content of the selected species varied from 2.49 (L. rohita) to $2.55 \mathrm{~g} / \mathrm{kg}$ (small prawns), 0.043 (H. molitrix and P. sophore) to $0.184 \mathrm{~g} / \mathrm{kg}$ (C. mrigala) and 0.94 (L. rohita) to $1.91 \mathrm{~g} / \mathrm{kg}$ (P.sophore), respectively.
\end{abstract}

Keywords: food quality, minerals, proximate composition, quality assessment, nutrition

Cite This Article: S. N. Jahan, M. A. Bayezid, B. Islam, M. A. B Siddique, P. K. Karmokar, and F. A. Flowra, “Biochemical Quality Assessment of Fish Powder.” American Journal of Food and Nutrition, vol. 5, no. 3 (2017): 110-114. doi: 10.12691/ajfn-5-3-6.

\section{Introduction}

Dried fish is an important source of protein and most popular food item in Bangladesh. It is relished by many people of coastal, central and North-eastern districts [1]. But many people of Bangladesh do not like dried fish for its fishy smell. In view of this problem, fish powder, which is less likely to produce unpleasant fishy odour while incorporated in various food items, would be a potential source of protein and serve as a new approach adding new dimension in nutritional intake, which ultimately could turn out to be promising source with respect to mitigating nutritional deficiency. Dried fish is also a rich source of protein, lipid, calcium, iron and zinc [2]. As dried fish is the raw material of fish powder, which is the rich source of nutrition, knowledge of nutritional composition of fish powder is essential in order to compare its value as food with other protein foods. It is also necessary to have data on the nutritional composition of fish powder in order to make the best use of them as food and to develop the technology of processing fish powder and other fisheries food items. In spite of huge amount of fish protein consumption in Bangladesh, there are a few reports on the nutritive or caloric values of dried fishes, very few in case of fish powder and rare in the selected species. As a result, people are confused to take required amount of calorie from fishes and fish products.
There are some related studies [3-13] focusing on the biochemical and nutritional studies of some freshwater raw as well as dried fish species. Although several studies are concerned with the proximate composition of biochemical components of many commercially important fishes, but no such work has been carried out on the selected fish powder of Bangladesh. Therefore, the present study is intended to estimate the amount of total protein, fat, moisture, ash, carbohydrate, phosphorus, iron, and calcium content of fish powder of some fishes and small prawns in order to make the consumers more attentive on the nutritional content of fish powder as well as this information will be also useful to consumers in choosing fish powder fortified products based on its nutrient values.

\section{Materials and Methods}

Five samples namely Silver carp (Hypophthalmicthys molitrix), Rui (Labeo rohita), Mrigel (Cirrnina mrigala), Punti (Puntius sophore) and small prawns (Macrobrachium dayanum, Macrobrachium macolmsonii, Macrobrachium lamarrei and Macrobrachium dolichodactylus) were collected from five fish markets such as Shaheb bazar fish market, Binodpur fish market, Shalbagan fish market, Laxmipur fish market and Court bazar fish market of Rajshahi city corporation, Bangladesh. The collected samples were brought into the laboratory of department of Fisheries, University of Rajshahi. 


\subsection{Processing of Samples}

Collected fish samples were washed in potable water for several times to remove dirt and debris's on the surface. Gutting was done to avoid microbial contamination as well as head and fins were removed and washed properly in running tap water. Then the samples were dried under sunlight and open air and milled into powder with the help of kitchen blender and sieved for the separation of bone.

\subsection{Estimation of Proximate Composition}

Proximate composition of fish powder (protein, lipid, moisture, ash and carbohydrate) was determined according to the standard methods. Protein of fish powder products was determined by Micro-Kjeldahl distillation method [14]. Lipid content of powder products was determined by petroleum ether extraction followed by soxhelt apparatus [15]. Moisture content was analyzed by moisture analyzer (MAC 50/NH) whereas the ash content was determined as described by following method [16]. The percentage of carbohydrate was calculated following the method [17].

\subsection{Estimation of Minerals}

Minerals of powder products such as phosphorus, calcium and iron were determined according to the standard methods. Phosphorus was determined by the Vanadomolybdate yellow colour method [18] and calcium was measured by flame method [19]. Iron concentration was measured by using APHA through Atomic Absorption Spectrophotometer (ELICO, SL 194 Model).

\subsection{Statistical Analysis}

Mean \pm Standard Deviation (Mean \pm SD) of proximate composition of dried fish powder was computed. Results obtained from proximate composition analysis for dried fish powder of different species were analyzed by ANOVA for significant differences. If there is significant difference among powder samples prepared from different species, ANOVA was followed by Post Hoc comparison of means and Duncan's Multiple Range Test (DMRT) was carried out using SPSS 20 software.

\section{Results and Discussion}

Mean \pm Standard Deviation values obtained from proximate compositional analysis of dried fish powder which includes moisture, protein, fat, ash and carbohydrate are tabulated in Table 1.

\subsection{Protein Content}

The highest value of protein was found in small prawns (68.50\%) and the lowest value was recorded in $P$. sophore (54.31\%) (Figure 1). Duncan's Multiple Range Test for protein examined among five dried fishes reveals that small prawns and C. mrigala are not significantly different $(\mathrm{P}>0.05)$ whereas other samples of dried fish powder are significantly different $(\mathrm{P}<0.05)$ with respect to different species (Table I). In a study [12] protein content ranged from 52.66 to $72.45 \%$ in seven dried fishes. These findings are more or less similar with the present study. Another study [20] reported that normally the sun-dried fishes contain 60 to $80 \%$ protein. From the study [21] it was found that the protein content in fish might vary with species to species due to certain factors such as the season of the year, effect of spawning and migration, food availability etc.

\subsection{Lipid Content}

Lipid contents of powder form different fish species and small prawns are shown in Figure 1. The highest value of lipid content was recorded in L. rohita (19.33\%) and the lowest was in $P$. sophore $(13.33 \%)$. In case mean values of lipid, for $L$. rohita and $H$. molitrix; and also for $P$. sophore and small prawns, no significant difference $(\mathrm{P}>0.05)$ is found between them however C. mrigala exhibited significant difference $(\mathrm{P}<0.05)$ among all species. One study [22] obtained 3.7 to $17.8 \%$ fat in 23 sun-dried fish species which is more or less similar with present study. Another research [23] revealed that dried Rita rita contained $13.92 \%$ lipid and also mentioned that lipid content also varies from species to species. The high content of lipid could be due to the larger size of fish.

\subsection{Moisture}

The highest moisture content was found in H. molitrix (13.95\%) and lowest was found in L. rohita (11.55) (Figure 1). In terms of average moisture content in dried fish powder samples, no significant difference is noticed among all species except $L$. rohita. From a research [12] it was noticed that moisture ranged from $11.65-13.50 \%$ in seven dried fishes. The present findings are more or less similar with the referred values. One study [20] mentioned that normally the sun-dried fishes contain an average of 10 to $20 \%$ moisture. Another study [24] reported that the moisture content of traditionally dried rui (L. rohita) was $9.07 \%$. Besides, the percentage may also vary according to size, sex and season of the year [25].

Table 1. Nutritional composition of fish powder of the selected species

\begin{tabular}{|c|c|c|c|c|c|}
\hline Species & Protein(\%) & Fat(\%) & Moisture(\%) & Ash(\%) & Carbohydrate(\%) \\
\hline L. rohita & $66.90 \pm 2.26^{\mathrm{ab}}$ & $19.33 \pm 1.79^{\mathrm{a}}$ & $11.55 \pm 2.27^{\mathrm{b}}$ & $0.24 \pm 0.07^{\mathrm{c}}$ & $1.75 \pm 1.75^{\mathrm{c}}$ \\
\hline C. mrigala & $68.46 \pm 2.37^{\mathrm{a}}$ & $15.71 \pm 2.14^{\mathrm{ab}}$ & $13.63 \pm 0.61^{\mathrm{a}}$ & $0.44 \pm 0.20^{\mathrm{a}}$ & $4.85 \pm 0.34^{\mathrm{b}}$ \\
\hline H. molitrix & $62.18 \pm 2.64^{\mathrm{b}}$ & $18.65 \pm 3.78^{\mathrm{a}}$ & $13.95 \pm 0.68^{\mathrm{a}}$ & $0.36 \pm 0.24^{\mathrm{b}}$ & $1.98 \pm 0.38^{\mathrm{c}}$ \\
\hline P. sophore & $54.31 \pm 3.54^{\mathrm{c}}$ & $13.33 \pm 0.23^{\mathrm{b}}$ & $12.85 \pm 1.10^{\mathrm{a}}$ & $0.28 \pm 0.0 .24^{\mathrm{c}}$ & $19.23 \pm 1.19^{\mathrm{a}}$ \\
\hline Small prawn & $68.50 \pm 2.01^{\mathrm{a}}$ & $13.63 \pm 0.55^{\mathrm{b}}$ & $12.30 \pm 0.74^{\mathrm{a}}$ & $0.16 \pm 0.26^{\mathrm{d}}$ & $5.4 \pm 1.04^{\mathrm{b}}$ \\
\hline
\end{tabular}

Values (Mean \pm SD) with different superscripts in columns are significantly different at $\mathrm{p}<0.05$. 


\subsection{Ash Content}

The highest ash content was found in C. mrigala $(0.44 \%)$ and lowest in small prawns $(0.16 \%)$ (Figure 1$)$. With respect to average amount of ash, L. rohita and $P$. sophore are not significantly different $(\mathrm{P}>0.05)$ whereas others are significantly different in respect of species. In a study [8] it was reported that the ash content of $C$. reba was $1.7 \%$ which is higher than the present study. Another study [26] also found higher amount of ash content in C. gariepinus (3.06\%) which is more higher than the studied fish species and small prawns whereas other study [27] mentioned that lower amount of ash content in six freshwater fishes such as L. rohita (1.31\%), C. catla (0.93\%), C. cirrhosus $(1.40 \%)$, L. calabasu
(1.02\%), M. seenghala (0.91\%) and W. attu (0.72) which is more or less same with the present study.

\subsection{Carbohydrate}

The highest value of carbohydrate was $19.23 \%$ (P. sophore) and the lowest was $1.75 \%$ (C. mrigala). In case of carbohydrate, $P$. sophore showed significant difference among all species whereas $L$. rohita and H. molitrix; C. mrigala and small prawns did not differ significantly between species $(\mathrm{P}>0.05)$. From one research [28] 1 - 12.5\% carbohydrate was found in the liver of dried fishes which is lower than the present study, as the present study is concerned with the fish powder from dried fish flesh.

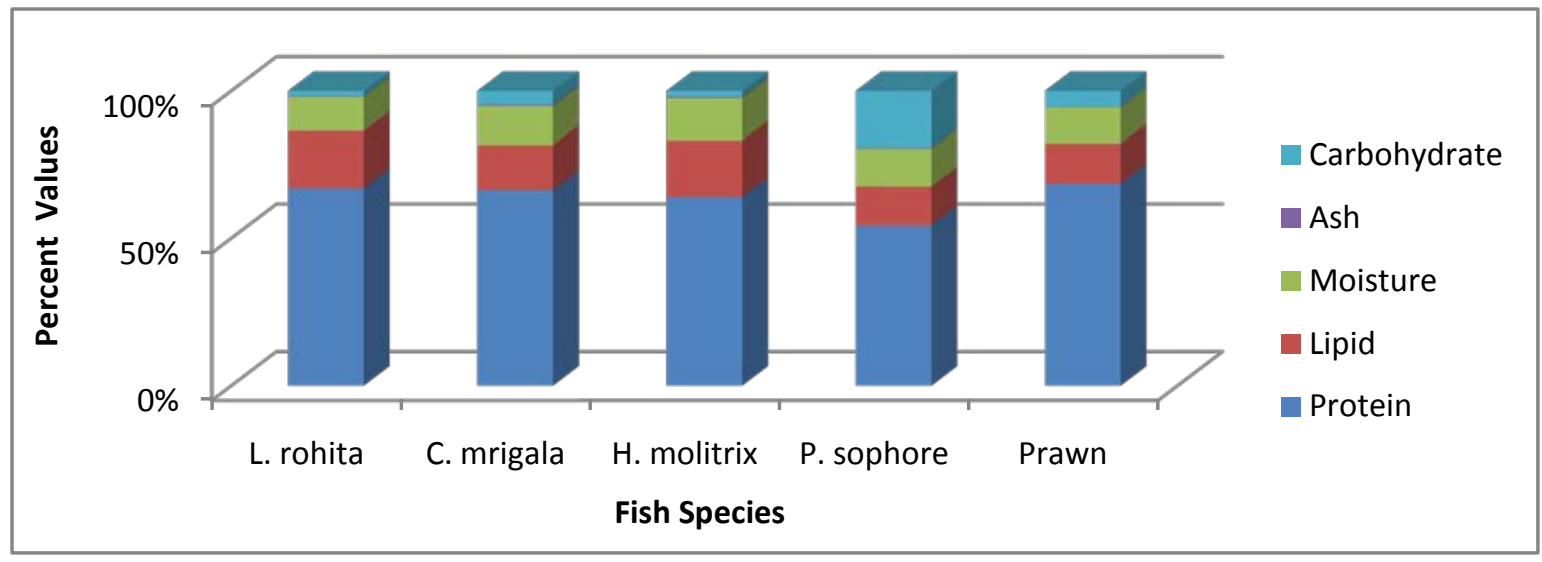

Figure 1. Pie diagram showing the nutrient compositions of powder form of different fish species and prawns
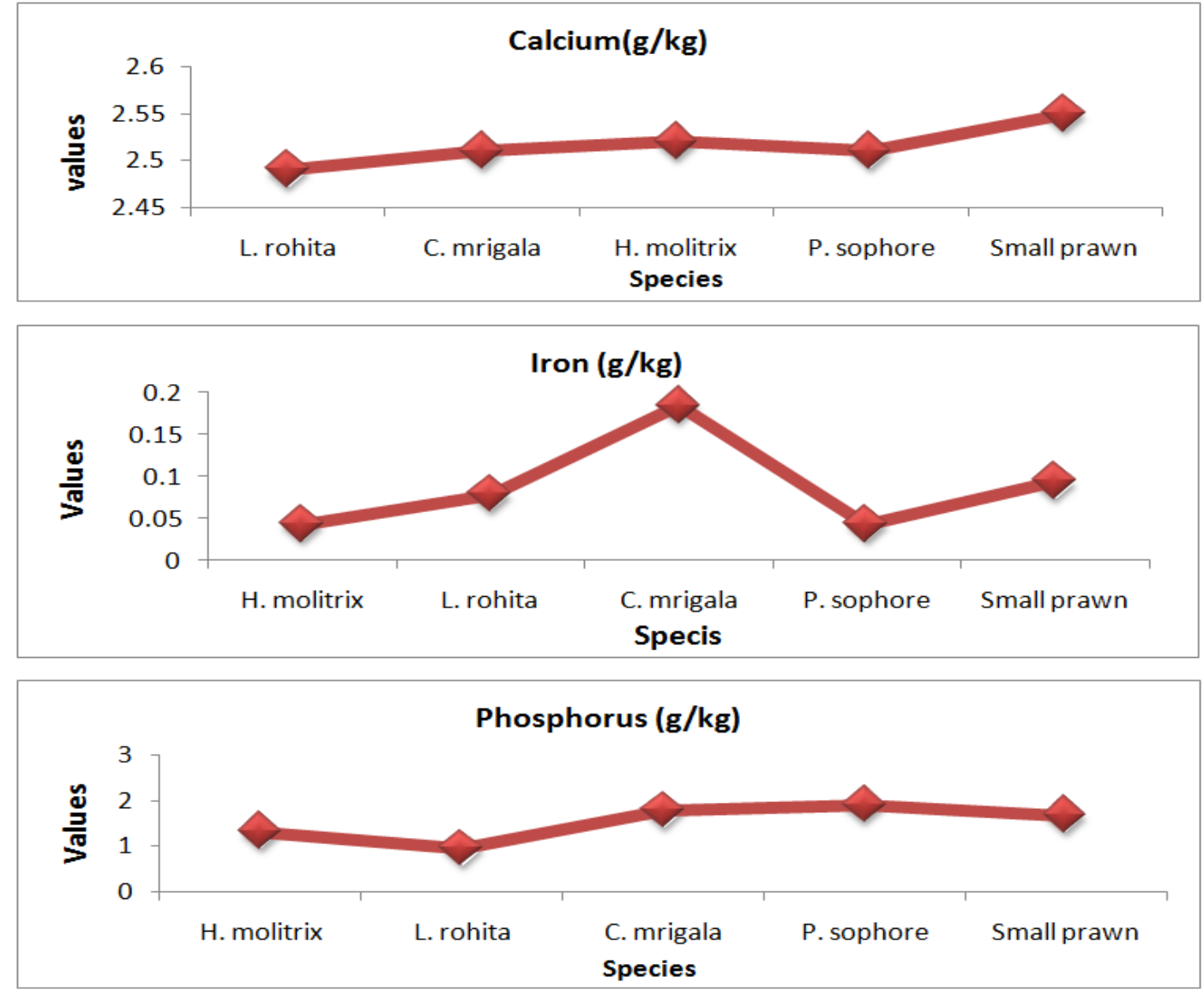

Figure 2. Showing the minerals contents of powder form of different fish species and small prawns 


\subsection{Calcium Content}

The highest calcium content was found in small prawns $(2.54 \mathrm{~g} / \mathrm{kg})$ and lowest in L. rohita, $(2.48 \mathrm{~g} / \mathrm{kg})$ (Figure 2). However, no significant difference in calcium content is noticed among all species. Calcium plays essential role in human body for the formation of bones muscle tone and nervous impulse [23]. One study reported that Cirrhina reba contains $822 \mathrm{mg}$ calcium/100g of fish [8].

\subsection{Iron Content}

The highest iron content was found in C. mrigala $(0.184 \mathrm{~g} / \mathrm{kg})$ and lowest in $H$. molitrix and $P$. sophore $(0.043 \mathrm{~g} / \mathrm{kg})$ (Figure 2$)$. With respect to iron content in various species, $L$. rohita and small prawns; $P$. sophore and $H$. molitrix showed no significant difference $(\mathrm{P}>0.05)$ between them except $C$. mrigala, however, these groups significantly differed among them. One study [12] found that the iron content was $16.85 \mathrm{mg} / 100 \mathrm{~g}$ in different dried fish. Another study [7] reported that iron was present at a range from 14.50 to $42.20 \mathrm{mg} / 100 \mathrm{~g}$ of raw fish, This discrepancy could be attributed to the factors affecting the iron content; such as species, individuals, and sampling period [29].

\subsection{Phosphorus Content}

The highest phosphorus content was found in $P$. sophore $(1.91 \mathrm{~g} / \mathrm{kg})$ and lowest in L. rohita $(0.94 \mathrm{~g} / \mathrm{kg})$ (Figure 2). Other than small prawns, no significant difference $(\mathrm{P}>0.05)$ was observed between $L$. rohita and $H$. molitrix; $C$. mrigala and $P$. sophore, yet significant difference were seen among this group. One study [30] showed that such variation in concentrations of mineral elements from one species to another was due to the chemical forms of the elements and their concentrations in the local environment. Another study [31] reported that Burrito fish (Brachydeuterus auritus) contains $93.71 \mathrm{mg} / 100 \mathrm{~g}$ phosphorus which is near to the present study. Such low concentration of phosphorus might be due to the removing of head, bones and scales from the fish body.

\section{Conclusion}

The results of the present study reveal that fish powder is equally nutritious almost in every aspects and even more nutritive than fresh fish so far as protein percent is concerned. Fish powder provides high level of protein with rich supply of iron, calcium and phosphorous, the essential minerals for human life. So in respect of nutritional security, powder of fish and small prawns may play as a crucial source to meet the demand of protein and minerals. Therefore, it can be concluded that fish powder product from both small and large fish and small prawns can be included in daily diet in order to satisfy the ever increasing nutritional requirement of the country.

\section{References}

[1] Nowsad, A. K. M. "Low cost processing of fish in coastal Bangladesh. Empowerment of coastal fishing communities for livelihood security," GOB/UNDP/FAO Project: BGD/97/017: 5/2005, p.73. 2005.
[2] Basu, K. P. and Gupta, K. "Biological value of protein of some species of Bengal fish by nitrogen balance and growth methods," J. of Indian chem. soc., Calcatta, pp. 543-548, 2004.

[3] Stansby, M. E. "Proximate composition of fishes," In: Fish in Nutrition, Ed. By E. Heen and R. Kreuzer. Fishing News (Books) Ltd., Ludgate House, 110 Fleet Street, London, E.C. England, p. 55, 1955.

[4] Gheyasuddin, S., Rahman, A. and M. Mumtazuddin, "Biochemical composition of shellfishes of Bangladesh," Bangladesh J. Sci. Res., vol. 2, pp. 15-23, 1979.

[5] Rubbi, S. F., Mujibar, M., Khan, A. R., Jahan, S. S. and Majeda, B "Proximate composition and quality of some commercial species of fresh water fish," Bangladesh J. Sci. Res., vol. 5, no. 1, pp. 1-20 1987.

[6] Mollah, A. H., Hasan, F., Azad, T. M. A., Salam, S. M. A. and Alarn, M. T. "Biochemical and nutritional status of Eutropichtys vacha (Ham-Buchanan)," J. Bio. Sci., vol. 8. pp. 23-26, 2000.

[7] Nurullah, M., Kamal, M., Wahab, M. A., Islam, M. N., Ahsan, C. T. and Thilsted, S. H. "Nutritional quality of some small indigenous fish species of Bangladesh," In: Small indigenous species of fish in Bangladesh (MA Wahab, SH Thilsted and ME Hoq eds.), Bangladesh Agricultural University, Mymensingh, Bangladesh, pp. 151-158, 2003.

[8] Islam, M. A., Mohsin, A. B. M., Bhuiyan, A. S. and Absar, N. "Biochemical composition and nutritional value of Cirrhina reba (Hamilton, 1822) of Bangladesh," J. bio-sci., vol. 11, pp. 127-130, 2003.

[9] Nowsad, A. K. M. "A new method of fish drying in a solar dryer(in Bengali)," Food and Agriculture Organization of the United Nationjs. BGD/97/017, p. 5, 2003.

[10] Naser, M. N., Chowdhury, G. W., Begum, M. M. and Haque, W. "Proximate composition of prawn, Macrobrachium rosenbergii and shrimp, Penaeus monodon," Dhaka Univ. J. Biol. Sci., vol. 16, no.1, pp. 61-66, 2007.

[11] Mazumder, M. S. A., Rahman, M. M., Ahmed, A. T. A., Begum, M. and Hossain, M. A. "Proximate compo- sition of some small indigenous fish species (SIS) in Bangladesh," International Journal of Sustainable Crop Production, vol. 3. pp. 18-23, 2008.

[12] Sultana, S., Parween, S. and Hossain, M. A. "Biochemical analysis of some dried sis fishes of the river padma in Rajshahi," J. Life Earth Sci. vol. 6, pp. 39-43, 2011.

[13] Flowra, F. A., Nahar, D. G., Tumpa, A. S. and Islam, M. D. "Biochemical Analysis of Five Dried Fish Species of Bangladesh". Univ. J. of Zool. Rajshahi Univ., vol. 31, pp. 9-11, 2012.

[14] A. O. A. C (Association of Official Agrichemicals), "Official Methods of Analysis of the Association of Official Agricultural Chemist," HeIritz, K. (Ed.). 15th Ed. Vol.2. Association of Official Analytical Chemists, Inc., Suite 400, 2200 Wilson Boulevard, Arlington, Virginia 22201 USA, p. 685-129, 1990.

[15] Jinadasa, B. K. K. K. "Determination of fat," GS/M.Sc/Food/3608/08., 2010.

[16] A. O. A. C (Association of Official Agrichemicals), "Official and tentative Methods of Analysis of the Association of Official and Agricultural Chemists," 8 ${ }^{\text {th }}$ Ed. Washington, pp. 468-470, 1955.

[17] Nurnadia, A. A., Azrina, A. and Amin, I. "Proximate composition and energetic value of selected marine fish and shellfish from the West coast of Peninsular Malaysia," J. of Int. Food Res., vol. 18, pp. 137-148, 2011.

[18] Bhargava, B. S. and Raghupathi, H. B. "Methods of Analysis of soils, Plants, Waters, Fertilizers and Organic Manures," Second edn edited by Tondon HLS., Fertilizer Development and Consultation organization, New Delhi, pp. 87-88, 2005.

[19] Perkin-Elmer, "Analytical methods for Atomic Absorption Spectroscopy," Perkin - Elmer Corp., U.S.A., pp. 1-300, 1982.

[20] Hoq, E. "Bangladesher Chhoto Mach (A book on small indigenous fish species of Bangladesh)," Published by Graphic Sign, Mymensingh 2200, pp. 81-84, 2004.

[21] Effiong, B. N. and Tafa, J. L. "Proximate composition of nutrients in adult Clarias gariepinus, Heterobranchus longifilis and their hybrid,"Proceedings of the 20th Annual conference of Fisheries Society of Nigeria, 14th-18th Nov., pp. 550-553, 2005.

[22] Hussain, M. M., Karim, A., Alam, Z., Islam, M. S., Khan, A. and Hossain, A. "Effect of pre-treatment on the drying of ghonia fish Labeo gonius in the open sun and in a solar tent," Bangladesh $\mathrm{J}$. Zool., vol. 20, pp. 231-238, 1992.

[23] Mollah, A. H., Rahman, M. S. and Alam, M. T. "Study on proximate chemical analysis of Bangladeshi freshwater fish Rita 
rita (Ham.) and seasonal variation of lipid, protein and related substances," Univ. j. zool., Rajshahi Univ. vol. 17, pp. 1-6, 1998.

[24] Islam, M. N. "Combined solar and cabinet drying of fishes," J. Ins. Enggs., Bangladesh. vol. 4, no. 19, pp. 7-11, 1982.

[25] Minar, M. H., Adhikary, R. K., Begum, M., Islam, M. R. and Akter, T. "Proximate composition of Hilsa (Tenualosa ilisha) in laboratory condition," Bangladesh J. Progress. Sci. and Technol., vol. 10, pp. 57-60, 2012.

[26] Chakwu, O. and Shaba, I. M. "Effect of drying method on proximate composition of cat fish (Clarial gariepinus)," J. World Agric. Sci., vol. 5, pp. 114-116, 2005.

[27] Devadsan, K., Varma, P. H. G. and Ventatraman, R. "Studies on Frozen Storage Characteristics of Fillets from Six Species of Freshwater Fish," Fish Tech. India. pp.1-6, 1978.
[28] Stirling, H. P. "The Proximate Composition of the Euro-pean Bass, Dicentratchus labrax (L.) from the Bay of Neples,” ICES Journal of Marine Science, Vol. 34, No. 3, pp. 357-364. 1972.

[29] Yilmaz, A. B., Sangun, M. K., Yanghoglu, D. and Turan, C. "Metals (major, essential to non-essential) composition of the different tissue of 3 demersal fish species from Iskenderun Bay, Turkey," J. of Food Chemistry, vol. 123, no. 2. pp. 410-415, 2010.

[30] Windom, H., Stein, D., Scheldon, R. and Smith, J. R. "Comparison of trace metal concentrations in metals (major, essential to non-essential) composition of the different tissue of 3 demersal fish species from Iskenderun Bay, Turkey," Food Chemistry, vol.123, no. 2, pp. 410-415, 1987.

[31] Abbey, L., Amengor, M. G., Atikpo, M. O., Atter, A. and Toppe, J. "Nutrient content of fish powder from low value fish and fish byproducts," Food Science and Nutrition, 5(3):374-379, 2017. 